\title{
The Education of Housecraft Teachers in Nutrition (England and Wales)
}

\author{
By Eleanor R. House, H.M. Inspector of Schools, Ministry of Education, Curzon
}

Street, London, W.I

\section{Introduction}

Girls who are proposing to make a career as domestic science teachers have a wide range of Colleges from which to choose for their training. Some of these will have a bias towards one or other facet of a many sided subject, which may influence the choice of a particular student. But the general object of these Colleges is to prepare students to be teachers of the comprehensive subject variously known as domestic science, domestic arts, domestic economy or housecraft. The central focus of the 3 -year course is the home and all that goes on in it to contribute to the total wellbeing of the members of the household. Of necessity nutrition forms one of the most important branches of study since, in its physical state at least, the well-being of the family is largely dependent on good nutrition.

\section{Discussion}

The preparation of students in the field of nutrition before entering College is most varied. Some may have taken domestic science in the General Certificate of Education, but the amount of nutritional knowledge required for this differs with the demands of the different University examining bodies and is never more than a simple understanding of food values and their translation into well cooked and well served meals. With the development of an advanced level for the subject in this examination the standard of knowledge required will be raised. Some students may have studied one or other branch of science, occasionally as well as domestic science; this is most often biology or general science and more rarely chemistry, but at all events such students will have some scientific knowledge upon which to build their later study of nutrition. Other students will go to College with little background knowledge in this subject, except such as they have culled in everyday life, that is, their personal experience. Though all students will have this, it is a factor not to be dismissed lightly. There are, perhaps, few other matters upon which everyone claims to have real knowledge from his own experience, or that of his acquaintances, and very few in which habits and prejudices are so easily formed, so deeply rooted and so difficult to change or eradicate even as early in life as the student age of $18-21$.

Education in nutrition during the Domestic Science Teacher Training Course follows four lines, each of which is closely related to all of the others.

The choice, preparation and service of food. This obviously covers a wide field; without an understanding of the source, composition and values of the different foodstuffs used, without a knowledge of the effects of different methods of cooking upon the nutritive values of these foods and without an appreciation of the 
nutritional needs of men, women and children in different circumstances and conditions of life, the practical processes of the preparation and service of food would be but a small part of education in nutrition. All these matters are therefore considered, so that the students learn how to select wisely for any particular group of people, or particular occasion, and how also to present the essential ingredients for sound nutrition in an attractive and palatable form and at a cost to suit the purse of those for whom the meals are being provided.

Science. The level to which science is studied varies from college to college and in groups within the same college, since, as shown above, the students may have a wide variety of scientific knowledge. A basic knowledge of elementary chemistry is imperative; if a student lacks it on entering College she will have special coaching for it. The course will then include the fundamentals of organic chemistry, as a basis for the chemistry of foodstuffs and their analysis, and some anatomy and physiology, particularly in relation to the digestive and excretory systems of the body. Some colleges will carry out dietary experiments with animals, and all will encourage the students to plan diets for particular persons or occasions and to watch their own diets in relation to their weights and general health. A close connexion is maintained between the work in the science laboratory and that in the kitchens.

Elementary bacteriology forms another section of the science course connected with that of nutrition. The study of yeasts and moulds is related to the preservation of foods, and some knowledge of bacteria is essential to an understanding of kitchen and domestic hygiene and such matters as infectious diseases and water supplies. It must be remembered that the science course in these colleges has a bearing on all facets of home life and will therefore include a great deal more than is mentioned here, since this paper deals only with nutrition education.

The practice of good nutrition. This is a pleasing aspect of the subject and awakens real interest in nearly every student. All women are, or should be, interested in their figures and very often the student age can be an ungainly one. It therefore gives point to the work she is doing and peculiar pleasure and interest to herself when a girl begins to understand the meaning of good nutrition and finds that by putting into practice what is being preached to her she can adjust her weight and improve her health and appearance. Students are encouraged to study the practice of good and poor nutritional habits, not only in themselves but also in those around them; to notice what is offered in cafeteria and restaurant menus and what is selected from them; to watch the meals given to children in the schools; and in these international days to make inquiry into the feeding habits of other nations and to compare them with their own. This type of observation and study should be of interest to the students and of value in later life when, as teachers, they may find themselves responsible for the feeding of groups of children or adults.

Teaching nutrition to children. This is perhaps the most difficult of the four lines that the nutrition education of the potential teacher of domestic science has to follow. The student must learn to have confidence in herself, not only as a teacher, but also as a craftswoman; she must be able to select appropriate matter for her 
class and be able to teach it convincingly. Neither of these is as simple as it may sound; matter that is applicable as nutrition education for one type of class and community may well be out of place in many another. In the same way methods of instruction that are quickly followed and understood in one place may cut no ice at all elsewhere.

What then are the criteria by which a potential domestic science teacher learns to select appropriate material for education of her classes in nutrition ? She must consider the environment from which the children come, their ages and mental ability, and she must be in sufficient sympathy with the children to get to know something of their home circumstances and problems.

There are many methods that may be used for this instruction, and the wise teacher will make use of them all as occasion demands. This applies to the lecturer in the training college no less than to the teacher in the school. Nutrition is in many ways an easy subject to teach; it appeals, as few others do, to all the senses, and the practice of it will give visible results and real satisfaction.

The practical demonstration, whether in kitchen or chemical laboratory, the microscope, the film and film strip, posters, charts and models of many kinds are all made use of in teaching nutrition to both students and children. But one of the most important of all methods is the practice of good nutritional habits in young and old alike.

\section{Equipping the teacher}

Clearly these four lines in the nutritional education of the student-in-training intersect at many points; a scientific background is imperative for the teacher; knowledge and practical skill are basic to the selection, preparation and service of food; both of these underlie the practice of good nutrition, and all are required by the teacher who hopes to be successful in spreading its gospel.

The student has thus every help in the preparation of her career and the practising teacher is not forgotten. From time to time refresher courses are held up and down the country for domestic science teachers, and many do attend them. But practising teachers should do more to keep their own nutritional knowledge up-to-date by reading, by membership of suitable organizations and by attendance at lectures and exhibitions. It would be most helpful if publications dealing with current nutritional research could be more readily available to teachers than they are at present. All too often, especially during the early years of her career, the domestic science teacher lives in lodgings where she has little or no opportunity for practical exercise of her nutritional knowledge. It is therefore all the more important that she should take and make opportunities for keeping abreast with current developments.

It is perhaps in the realm of nutrition education that the domestic science teacher finds most satisfaction and can most readily point to her successes. Pupils will return in later years to express gratitude for what they learned and for the help that knowledge has been to them. The babies and the young children of Britain are healthier and lovelier than they have ever been before, and it is no exaggeration 
to say that the work of the domestic science teachers in nutrition education has played a vital part in this happy state of affairs.

\title{
SUMMARY
}

The training colleges of domestic science offer a varied 3-year course; some have a definite bias towards one or other branch of this wide subject, but all build their work round the home and the needs of the various members of the household. Since good nutrition is a fundamental essential of family well-being, the study of nutrition education is common to all colleges. The previous preparation of students on entry to college varies considerably, but the nutrition course during their training follows four lines all leading to the practice of good nutritional habits based on scientific knowledge and to the ability to teach this to others. Though the student-in-training has ample help with her nutrition education, further stimulus and guidance are needed for the practising teachers, who all too often find it difficult to keep their nutrition knowledge up to date.

\section{The Education of Medical Students in Nutrition}

\author{
By S. J. Cowell, University College Hospital Medical School, \\ London, W.C.I
}

\section{The dual aspect of nutrition}

If and when we have agreed on an answer to the question 'What do practising doctors need to know about nutrition ?', we may be in a position to discuss the ways and means of giving medical students the knowledge they should be encouraged to acquire.

There are two distinct aspects of nutrition of importance to the medical practitioner. There is first the knowledge of general principles, which on the one hand will enable him to secure for the individuals and families in his care the perfection of development in early years that depends on right feeding and on the other hand will furnish him with a potent means of maintaining his older 'patients' in vigorous health. Secondly, the medical man requires a knowledge of how normal diets can be modified so that they may make their fullest contribution to the treatment of his individual patients when they fall sick.

I propose to give my views on the kind of knowledge of nutrition a medical man should possess and then to consider ways and means of giving it to the medical student. May I refer for a moment to the foundation in the University of London, in 1927 , of the Chair of Dietetics of which I am the original holder. This Chair was endowed through the initiative of a wealthy mother whose own doctor was unwilling or unable to offer her any advice, based on up-to-date nutritional science, on how to feed her young growing family. From inquiries she made it appeared that few, if any, clinical students at that time were being encouraged to take a real 